\title{
順 天堂医学投稿規程
}

1 、原稿本文は, 日本語とする

2. 原著は, 順天堂医学会会員の研究に限り, 刷上り 10 頁以内とし，4 頁以上は実費を徴収する.

3. 症例, 実験などの報告及び速報は, 刷上り 4 頁以内 とし，2 頁以上は実費を徴収する.

4. 綜説は, 長さに制限を設けないが B 5 版原稿用紙 （400字詰）50枚以内を希望する.

5 . 印刷代及び図, 写真などの製版代は, 著者負担とす る. 但し, 別刷は30部まで無料とする.

6. 原稿（プロムナード等を除く）には英文の表題, 所 属, 著者名を付記し, 原著論文はさらに300語以内 の英文サマリ一と 500 字以内の和文抄録 (前文) 及 び 5 個以内のキーワード（和・英並記）をつける.

7. 投稿原稿（特集, プロムナ一ド, 余滴を除く）は, 副本 (コピー) 1 部を添付する.

8. 原稿の取捨選択, 掲載順序などは, 編集委員会が決 定する.

9. 原稿の送り先は, 下記の通り.

干113 東京都文京区本郷 2 丁目 1 番 1 号 順天堂大学内 順天堂医学編集室 電話03（813）3111内線3115

10. 原稿の書き方は, 次の要領による.

a . 原稿は, B 5 版横書 400 字詰原稿用紙を用いイン キ又はボールペン書き(ワープロは，B 5 白紙 そ横20字20行の印字) とし, 本誌専用の表紙を 附す.ホッチキスなどによる製本は不要である.

b. 原稿は, 当用漢字新仮名づか心平仮名まじり, 横書とし, 簡潔に楷書で書く.

c . 外国語は原語の場合は活字体（原則としてタイ
プ），邦文の場合は片仮名を用いる。

d. 数字は算用数字を用い, 単位は原則として CG $\mathrm{S}$ 単位による. 単位符号の後には点をつけない $(\mathrm{g}$. でなくg). 特殊の単位を用いる場合は必ず 簡単な説明を加える.

e . 挿図及び表は本文とは別にし図 1 , 表 1 などの 番号および表題, 説明をつける. 本文中の挿入 すべき場所の右闌外に別に朱字でその位置を指 定する. 図の原稿は，そのまま製版できるもの とし, 台紙の大きさはB 5 版とする.

f . 文献は引用順とし, 末尾文献リストの番号を片 括弧に入れて右上肩につける。(例, 橋本ら" によれば……... ) 文献が共著のときは 3 名ま での連記とし，3 名以上は「他」「et al.」と する.

文献引用例【1，2)は雑誌の例，3)，4)は単行本の例】

1 ）橋本博史：全身性エリテマトーデスと免疫, 順天 堂医, $22 ： 253 \sim 264,1976$

2 ) Bridge, R. G. \& Foley, F. E.: Placental transmission of lupus erythematosus factor.

Am. J. Med. Sc., $227: 1 \sim 8,1954$

3 ) Enzinger, F. M., Weiss, S. W.: Soft tissue tumors. 45 70, The C. V. Mosby, St. Louis, 1983

4 ) 藤浪隆夫 : 高脂質血症の食事療法, 内科 Mook 19, 高脂質血症, 阿部正和他編, 234 250, 金原出 版, 東京, 1982

11. 投稿にあたっては，事前に編集室に連絡をとるてと. 原著論文については，別に定める投稿要領に従う。

\section{原稿 募 集}

会員諸氏に, より親しみやすく, 楽しく, 読みやすい雑誌とするために「医学プロムナード」に 加えて「診療ノ一ト」「余滴」の欄をもうけました.

この闌へので投稿内容は, 医学に関連した随筆, 先生の日常診療でで経験された興味ある症例, 経験から得られた診療の秘訣, 関係医師会における最新の話題, その他後輩に是非伝えたい医学的 知見, 研究上の興味ある話題など広く先生の身近な医学的事項についてで執筆願いたいと思います. 「プロムナード」は図表等を含め, 2,100〜2,900字 (刷上り 2 頁), 「診療ノート」, 「余滴」は300〜 500 字, 原稿締切日の限定はありませんが, 編集会議開催日の毎月第 3 木曜迄に到着するようご配慮下さい. なお，特集主題についても会員各位のご意見，で希望を編集室宛およせ下さい.

「順天堂医学」は広く, 医学界の新知識を紹介することを基本方針とし, 毎号特集形式で編集 する．その原稿は編集委員会から執筆者に依頼する．乙のほかに原著論文なども掲載するが，掲 載希望者は上記の投稿規程を守って戴きたい．依頼原稿（医学プロムナード等を含む）に対して は別に規定する原稿料を呈する．原著など投稿原稿については，規定の揭載料を徵収する. 